\title{
Intrastromal corneal ring segments delay corneal grafting in patients with keratoconus
}

\author{
Segmentos de anéis intracorneanos protelam o transplante de córnea em pacientes com ceratocone
}

Luiz Arthur F. Beniz ${ }^{1}$, Gustavo H. Queiroz ${ }^{1}$, Carlos F. Queiroz¹․ Wanessa L. Lopes ${ }^{1}$, Leiser F. Moraes¹, José Beniz ${ }^{1}$

\section{ABSTRACT}

Purpose: To assess the impact of intrastromal corneal ring segments (ICRS) as a surgical alternative to corneal grafting in patients with keratoconus who were scheduled for a corneal transplant.

Methods: This single-surgeon, single-center, retrospective, observational case series study included 19 eyes of 18 patients (mean age, $23.36 \pm 6.22$ years) with a confirmed diagnosis of keratoconus. These patients were enrolled from the State of Goiás, Brazil corneal graft waiting list. Following extensive pre-operative testing, including the measurement of best-corrected visual acuity (BCVA), applanation tonometry, biomicroscopy, funduscopy, pachymetry, and corneal topography, patients were implanted with Keraring ${ }^{\oplus}$ ICRS. Patients underwent clinical examination at postoperative days 1, 7, 30, 90, and 180 and were examined again 2 years following surgery.

Results: At the 2-year cut-off following ICRS implantation (mean follow-up, 28.72 \pm 4.71 months), there was a statistically significant improvement in BCVA (logMAR) from $0.59 \pm 0.35$ preoperatively to $0.35 \pm 0.45$ postoperatively $(p<0.01)$. Three of 19 eyes (15.8\%) still required keratoplasty. In the remaining patients (84.2\%), BCVA was managed with spectacles (52.6\%) or contact lenses (31.6\%). One patient developed infectious keratitis, requiring removal of ICR at the first postoperative visit. Conclusion: ICRS implantation may be a surgical alternative to keratoplasty in patients with keratoconus. This procedure may delay or even eliminate the need for keratoplasty in such patients.

Keywords: Keratoconus; Corneal transplantation; Corneal stroma; Eye banking; Visual acuity

\section{RESUMO}

Objetivo: Avaliar o impacto do implante de anéis corneanos intraestromais como alternativa cirúrgica à ceratoplastia, em pacientes com ceratocone previamente inscritos na fila de espera para transplante de córnea.

Métodos: Este estudo unicêntrico, retrospectivo, observacional analisou prontuários de 19 olhos de 18 pacientes (idade média de 23,36 \pm 6,22) com diagnóstico de ceratocone, incluídos na lista de espera para transplante de córnea do estado de Goiás, Brasil. Após realização de exame oftalmológico completo pré-operatório, incluindo acuidade visual (AV) corrigida, tonometria de aplanação, biomicroscopia, fundoscopia, paquimetria e topografia corneana, os pacientes foram submetidos a cirurgia para implante de anel intracorneano Keraring ${ }^{\circledR}$. Os mesmos foram submetidos a exame oftalmológico no 1ㅇ, 7ㅇ, 30, 90, 180 dias de pós-operatório, e também após 2 anos da cirurgia.

Resultado: Após a visita final de 2 anos de acompanhamento (média de seguimento de 28,72 $\pm 4,71$ meses), houve melhora estatisticamente significativa da AV corrigida $(\log M A R): 0,59 \pm 0,35$ no pré-operatório para 0,35 $\pm 0,45$ do pós-operatório $(p<0,01)$. Três dos 19 olhos $(15,8 \%)$ permaneceram com a indicação de ceratoplastia. A conduta para os demais $(84,2 \%)$ foi correção óptica com óculos $(52,6 \%)$ ou lente de contato $(31,6 \%)$. Um paciente evoluiu com ceratite infecciosa no pós-operatório, tendo seus anéis removidos.

Conclusão: O implante de anéis intraestromais mostrou ser uma alternativa eficaz ao transplante de córnea nesta série de casos. Esse procedimento pode ajudar a retardar ou eliminar a necessidade de indicação de ceratoplastia em pacientes com ceratocone.

Descritores: Ceratocone; Transplante de córnea; Banco de olhos; Estroma corneano; Acuidade visual

\section{INTRODUCTION}

Keratoconus is a common, non-inflammatory, progressive corneal disorder with a typical onset in early adulthood ${ }^{(1)}$. Keratoconus that is characterized by thinning and protrusion of the central cornea frequently leads to a mild-to-severe decrease in best-corrected visual acuity (BCVA). Loss of visual acuity can be improved with contact lenses or spectacles in the early stages of the disease; however, patients may eventually require corneal grafting as their condition progresses. Keratoconus is the single most common reason for keratoplasty in the developed world ${ }^{(1-3)}$.

Penetrating keratoplasty is associated with a high success rate and continues to play an important role in keratoconus management. However, it is also associated with significant complications, including immunological rejection, secondary cataract, glaucoma, and mi- crobial keratitis ${ }^{(4,5)}$. Moreover, visual rehabilitation or recovery of visual acuity following transplantation may be slow and unsatisfactory. There is a growing interest in treatment options that may delay or defer corneal grafting, including the use of intrastromal corneal ring segments $(\text { ICRS })^{(6)}$.

Originally used to correct mild-to-moderate myopia, ICRS exert an "arc-shortening" effect on the corneal lamellae, thus reducing steepening of the central cornea ${ }^{(3)}$. This decreases refractive errors and improves corneal surface regularity. Moreover, there is evidence to suggest that implanting an ICRS may delay the requirement for penetrating keratoplasty ${ }^{(7-9)}$

There are several commercially available ICRS that vary with regard to curvature, width, and zone of implantation ${ }^{(3)}$. One such ICRS is the Keraring (Mediphacos, Belo Horizonte, Brazil), a small, arc-like segment made of polymethyl methacrylate. It is characterized by a unique pris- 
matic design that flattens the cornea and reduces the incidence of glare and halos. Several clinical studies have demonstrated their efficacy in improving visual function, reducing the magnitude of corneal astigmatism, and flattening the central corneal surface ${ }^{(10-14)}$. Although previous studies have evaluated ICRS efficacy in patients who were intolerant to rigid contact lenses (and therefore potential candidates for a corneal transplant) ${ }^{(15-17)}$, to the best of our knowledge, there are no published data regarding Keraring ICRS efficacy in patients with keratoconus who were already scheduled for penetrating keratoplasty. Consequently, we performed a small case series study to determine whether Keraring ICRS implantation might represent a surgical alternative to corneal grafting in patients with keratoconus who were awaiting penetrating keratoplasty.

\section{METHODS}

We conducted a retrospective observational case series study on the basis of an analysis of records of patients included in the State of Goiás corneal graft waiting list. These patients underwent Keraring ICRS implantation as a potential alternative to keratoplasty. All procedures were performed by the same surgeon at the Centro de Referência em Oftalmologia UFG, Goiânia, Brazil between June and December 2008. Written informed consent was obtained prior to study and data collection.

The study included 18 patients (19 eyes) with a mean age of $23.36 \pm 6.22$ years and with keratoconus varying from Grade II to IV (Amsler-Krumeich scale). Patients were included if they had evidence of topographical alteration that was compatible with keratoconus, a minimal corneal thickness of $380 \mu \mathrm{m}$, low BCVA with spectacles, and intolerance to contact lenses. Exclusion criteria included topographic curves over 70 D, apical opacity, and external ocular infection. Baseline characteristics of the patients are summarized in table 1.

Prior to ICRS implantation, all patients underwent a detailed preoperative clinical assessment, including the measurement of BCVA (logMAR), applanation tonometry, biomicroscopy, fundoscopy, pachymetry, and corneal topography. Patients were postoperatively evaluated for BCVA.

ICRS selection was based on the Mediphacos nomogram for the Keraring ${ }^{\circledR}$ calculation system (Belo Horizonte, Brazil). All surgeries were performed on an outpatient basis under topical anesthesia $(5 \mathrm{mg} / \mathrm{mL}$ proxymetacaine $\mathrm{HCl}$ and $5 \%$ povidone iodine). The ICRS tunnel was manually created. The center of the visual axis on the cornea was marked, and an initial perpendicular corneal incision was made at the 5-7-mm zone with an adequate depth for each case. This was followed by radio intrastromal channelization. Appropriate ICRS was finally placed inside the corneal tunnels.

Following the procedure, patients were administered Maxitro| ${ }^{\circledR}$ eye drops (Alcon Laboratories, Brazil) every 2 h for 2 weeks, followed by Florate ${ }^{\circledR}$ (Alcon Laboratories, Brazil) four times daily, also for 2 weeks.

Postoperative outcomes were evaluated at postoperative days 1 , $7,30,90,180$, and eventually 2 years following implantation. BCVA was measured and biomicroscopy and applanation tonometry were performed at each follow-up visit, whereas fundoscopy was performed at the 6-month follow-up visit. The effectiveness of ICRS in terms of preventing corneal grafting was evaluated at the 2-year follow-up visit.

\section{RESULTS}

Pre- and postoperative BCVA (logMAR) data of each patient are displayed in table 2. Mean preoperative BCVA was $0.59 \pm 0.35$. At the 2-year cut-off point following ICRS implantation (mean follow-up, $28.72 \pm 4.71$ months), mean BCVA was $0.35 \pm 0.45$ (Figure 1). This improvement in BCVA was statistically significant $(p<0.01)$. One patient developed infectious keratitis on postoperative day 1. Consequently, this patient had his corneal rings removed, and his data excluded from the statistical analysis of BCVA. The patient subsequently underwent corneal grafting.
At the 2-year cut-off point, 3/19 eyes (15.8\%) were still considered candidates for penetrating keratoplasty because they did not achieve significant corneal applanation or regularity. However, the remaining patients (84.2\%) maintained BCVA with spectacles (52.6\% patients) or contact lenses (31.6\% patients). Apart from one case of infectious keratitis, no other relevant complications occurred.

\section{DISCUSSION}

Although initially approved by the US Food and Drug Administration as a treatment for myopia, ICRS has become a mainstay in managing keratoconus. Since Colin et al. first reported regarding the use of ICRS in keratoconus more than a decade ago ${ }^{(7)}$, a plethora of studies have demonstrated their ability to effectively reduce refractive errors and safely improve corneal surface regularity. While there is also increasing evidence to suggest that ICRS may delay the requirement for penetrating keratoplasty ${ }^{(5,18)}$, published evidence describing ICRS effects in patients with keratoconus already scheduled to undergo penetrating keratoplasty is limited.

Table 1. Patient characteristics

\begin{tabular}{lc}
\hline & $\mathbf{N}(\%)$ \\
\hline № patients & 18 \\
Gender & $12^{*}$ \\
Female & 6 \\
Male & 19 \\
№ of eyes & 9 \\
$\quad$ Right eyes & 10 \\
Left eyes & \\
Age (years) & 23.36 e 6.22 \\
Mean & $14-32$ \\
Range &
\end{tabular}

Table 2. BCVA (logMAR) pre- and post-ICRS implantation

\begin{tabular}{ccc}
\hline Eye & Preoperative BCVA & Postoperative BCVA* \\
\hline 1 & 0.15 & 0.15 \\
2 & 0.53 & 0.30 \\
3 & 0.30 & 1.00 \\
4 & 1.00 & 0.30 \\
5 & 0.70 & 0.22 \\
6 & 0.70 & 0.53 \\
7 & 0.30 & 0.14 \\
8 & 0.70 & 0 \\
9 & 1.60 & 1.80 \\
10 & 0.40 & 0.15 \\
11 & 0.27 & 0 \\
12 & 0.40 & 0.53 \\
13 & 0.82 & 0.70 \\
14 & 0.10 & 0.10 \\
15 & 0.70 & 0.15 \\
16 & 0.70 & 0.04 \\
17 & 0.40 & 0.04 \\
18 & 0.40 & 0.20 \\
\hline
\end{tabular}

* = two-year cut-off point (mean follow-up, $28.72 \pm 4.71$ months); $\mathrm{NB}=$ one of 19 eyes included in the study was excluded from BCVA statistics. 


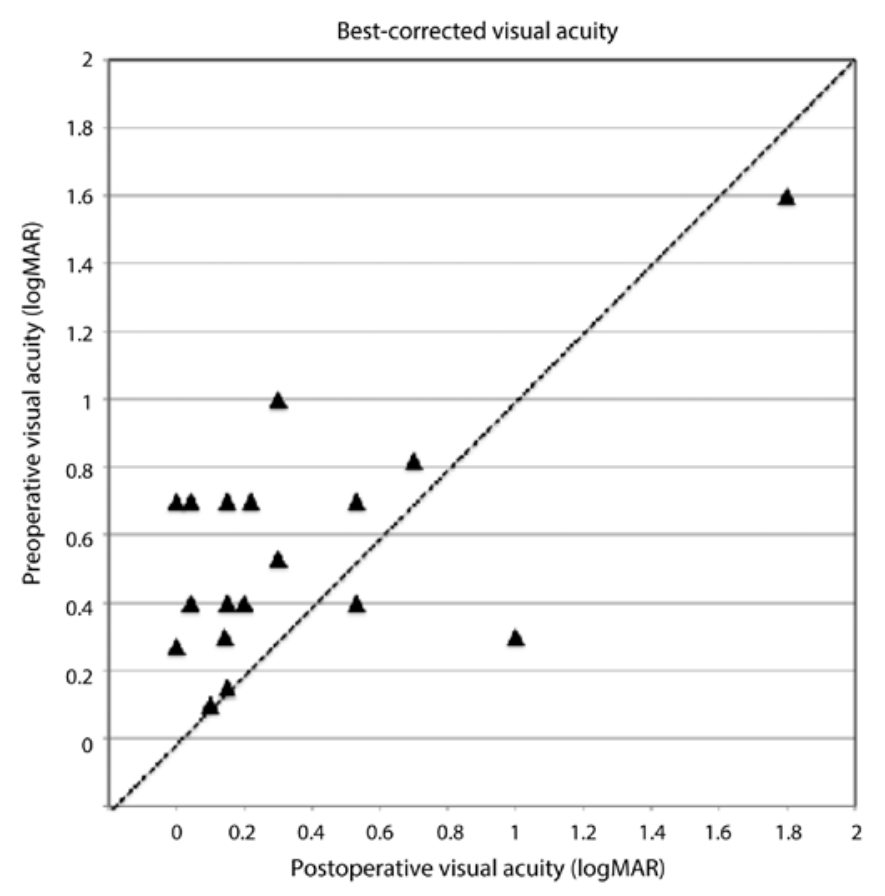

* = two-year cut-off point (mean follow-up, $28.72 \pm 4.71$ months). $\mathrm{NB}=$ one of 19 eyes included in the study was excluded from analysis of BCVA data.

Figure 1. Change in BCVA (logMAR) following ICRS implantation.

The results of our case series of 18 patients (19 eyes) who awaited corneal grafting suggest that ICRS may be an efficacious alternative to penetrating keratoplasty. At the 2-year data cut-off point, we noted that $84 \%$ eyes maintained BCVA with spectacles (52.6\%) or contact lenses (31.6\%), whereas 3/19 eyes (15.8\%) still required keratoplasty because they did not achieve significant corneal applanation or regularity.

Data from a previously published, one-year, 50-eye study demonstrated that Keraring ICRS implantation improved both uncorrected visual acuity and BCVA in patients with keratoconus ${ }^{(17)}$. Similarly, in a 35-eye study, Coimbra et al. demonstrated that Keraring ICRS improved visual acuity and topographic data in patients with secondary corneal ectasia at a 3-month postoperative follow-up ${ }^{(11)}$. However, to the best of our knowledge, no reports on the use of Keraring ICRS as a treatment for patients who have already been triaged for corneal transplantation are available. Consequently, it is somewhat difficult to discuss our findings within the context of others. However, there is a comparative case study of 76 eyes with advanced keratoconus. These patients received either ICRS implantation or deep anterior lamellar keratoplasty. ICRS effected a statistically significant increase in visual acuity (corrected and uncorrected distance visual acuity) from baseline to postoperative 24 months $(p<0.001)^{(19)}$. Similarly, data from a study by El-Husseiny et al., which included 20 eyes of 16 patients, revealed that ICRS (Intacs, Addition Technology, Inc, Sunnyvale, CA) provided a viable alternative to early penetrating keratoplasty for patients with keratoconus having a clear central cornea and a history of contact lens intolerance. Specifically, the data revealed that after 6 months of follow-up, the mean uncorrected distance visual acuity improved from $0.07 \pm 0.07$ preoperatively to $0.6 \pm 0.26$ postoperatively, whereas mean BCVA changed from $0.4 \pm 0.15$ preoperatively to $0.9 \pm 0.29$ postoperatively ${ }^{(20)}$.

Although data from our small study suggests that ICRS may be a surgical alternative to keratoplasty in some patients with keratoconus, longer-term follow-up is required to determine for how long ICRS adequately maintain BCVA and whether patients for whom ICRS implantation was effective will eventually require penetrating keratoplasty.

\section{CONCLUSION}

The results indicate that ICRS implantation may delay or even eliminate the requirement for corneal grafting in a group of patients with keratoconus who awaited keratoplasty.

\section{REFERENCES}

1. Davidson AE, Hayes S, Hardcastle AJ, Tuft SJ. The pathogenesis of keratoconus. Eye (Lond). 2013;28(2):189-95.

2. Rabinowitz YS. Keratoconus. Surv Ophthalmol. 1998;42(4):297-319.

3. Gharaibeh AM, Muhsen SM, AbuKhader IB, Ababneh OH, Abu-Ameerh MA, Albdour MD. KeraRing intrastromal corneal ring segments for correction of keratoconus. Cornea. 2012;31(2):115-20.

4. Lim L, Pesudovs K, Coster DJ. Penetrating keratoplasty for keratoconus: visual outcome and success. Ophthalmology. 2000;107(6):1125-31.

5. Rahman I, Carley F, Hillarby C, Brahma A, Tullo AB. Penetrating keratoplasty: indications, outcomes, and complications. Eye (Lond). 2009;23(6):1288-94.

6. Health Quality Ontario. Intrasomal corneal ring implants for corneal thinning disorders: an evidence-based analysis. Ont Health Technol Assess Ser. 2009;9(1):1-90.

7. Colin J, Cochener B, Savary G, Malet F. Correcting keratoconus with intracorneal rings. J Cataract Refract Surg. 2000;26(8):1117-22. Comment in: J Cataract Refract Surg. 2000; 26(8):1099-100. J Cataract Refract Surg. 2001;27(3):341.

8. Tunc Z, Helvacioglu F, Sencan S. Evaluation of intrastromal corneal ring segments for treatment of keratoconus with a mechanical implantation technique. Indian J Ophthalmol. 2013;61(5):218-25.

9. Lovisolo CF, Calossi A, Ottone AC. Intrastromal inserts in keratoconus and ecstatic corneal conditions. In: Lovisolo CF, Fleming JF, Pesando PM, editors. Intrastromal corneal ring segments. Canelli AT, Italy: Fabiano Editore; 2000. p. 95-163.

10. Haddad W, Fadlallah A, Dirani A, El Rami H, Fahd D, Khanafer D, et al. Comparison of 2 types of intrastromal corneal ring segments for keratoconus. J Cataract Refract Surg. 2012;38(7):1214-21.

11. Coimbra CC, Gomes MT, Campos M, Figueiroa Jr ES, Barbosa EP, Santos MS. Femtosecond assisted intrastromal corneal ring (ISCR) implantation for the treatment of corneal ectasia. Arq Bras Oftalmol. 2012;75(2):126-30.

12. Kubaloglu A, Sari ES, Cinar Y, Koytak A, Kurnaz E, Ozertürk Y. Intrastromal corneal ring segment implantation for the treatment of keratoconus. Cornea. 2011;30(1):11-7.

13. Piñero DP, Alió JL, Teus MA, Barraquer RI, Michael R, Jiménez R. Modification and refinement of astigmatism in keratoconic eyes with intrastromal corneal ring segments. J Cataract Refract Surg. 2010;36(9):1562-72.

14. Alfonso JF, Lisa C, Fernández-Vega L, Madrid-Costa D, Poo-López A, Montés-Micó R. Intrastromal corneal ring segments and posterior chamber phakic intraocular lens implantation for keratoconus correction. J Cataract Refract Surg. 2011;37(4):706-13.

15. Fahd DC, Jabbur NS, Awwad ST. Intrastromal corneal ring segment SK for moderate to severe keratoconus: a case series. J Refract Surg. 2012;28(10):701-5.

16. Kymionis GD, Siganos CS, Tsiklis NS, Anastasakis A, Yoo SH, Pallikaris Al, et al. Long-term follow-up of Intacs in keratoconus. Am J Ophthalmol. 2007;143(2):236-44.

17. Coskunseven E, Kymionis GD, Tsiklis NS, Atun S, Arslan E, Jankov MR, et al. One-year results of intrastromal corneal ring segment implantation (KeraRing) using femtosecond laser in patients with keratoconus. Am J Ophthalmol. 2008;145(5):775-9.

18. Ertan A, Colin J. Intracorneal rings for keratoconus and keratectasia. J Cataract Refract Surg. 2007;33(7):1303-14.

19. Ozertürk Y, Sari ES, Kubaloglu A, Koytak A, Piñero D, Akyol S. Comparison of deep anterior lamellar keratoplasty and intrastromal corneal ring segment implantation in advanced keratoconus. J Cataract Refract Surg. 2012;38(2):324-32.

20. El-Husseiny M, Tsintarakis T, Eppig T, Langenbucher A, Seitz B. [Intacs intracorneal ring segments in keratoconus]. Ophthalmologe. 2013;110(9):823-6. German. 